\title{
Interrelationships among International Stock Market Indices: Europe, Asia and the Americas.
}

\author{
Adel Sharkasi, Heather J. Ruskin and Martin Crane \\ School of Computing, Dublin City University, Dublin 9, IRELAND \\ Email: asharkasi, hruskin and mcrane@computing.dcu.ie
}

June 28, 2004

\begin{abstract}
In this paper, we investigate the price interdependence between seven international stock markets, namely Irish, UK, Portuguese, US, Brazilian, Japanese and Hong Kong, using a new testing method, based on the wavelet transform to reconstruct the data series, as suggested by Lee (2002). We find evidence of intra-European (Irish, UK and Portuguese) market co-movements with the US market also weakly influencing the Irish market. We also find co-movement between the US and Brazilian markets and similar intra-Asian co-movements (Japanese and Hong Kong). Finally, we conclude that the circle of impact is that of the European markets (Irish, UK and Portuguese) on both American markets (US and Brazilian), with these in turn impacting on the Asian markets (Japanese and Hong Kong) which in turn influence the European markets. In summary, we find evidence for intra-continental relationships and an increase in importance of international spillover effects since the mid 1990's, while the importance of historical transmissions has decreased since the beginning of this century.
\end{abstract}

keywords: Simple Regression, Volatility and Wavelet Analysis

\section{Introduction}

The relationships between international stock markets have been investigated in several articles, especially after "Black Monday" (October 1987). These 
studies indicated that co-movements among stock markets have increased the possibilities for national markets to be influenced by changes in foreign ones. For example, Eun and Shim (1989) investigated the relationships among nine major stock markets (Australia, Canada, France, Germany, Hong Kong, Japan, Switzerland, the UK and the US) using the Vector Autoregressive (VAR) model and reported that news beginning in the US market has the most influence on the other markets. Lin at el (1994) studied the interdependence between the returns and volatility of Japan and the US market indices using daytime and overnight returns. The results indicated that daytime returns in each market (US or Japan) are linked with the overnight returns in the other.

In addition, Kim and Rogers (1995) used $\mathrm{GARCH}^{1}$ to study the comovements between the stock markets of Korea, Japan, and the US and their result indicated that the spillovers from Japan and the US have increased since the Korean market became open for outsiders to own shares. Further, Booths et al. (1997) reported that there are significant spillover effects among Scandinavian stock markets (Danish, Norwegian, Swedish and Finnish) applying EGARCH ${ }^{2}$. Additionally, $\mathrm{CVM}^{3}$ (1998) investigated the link between the Asian and Brazilian markets as representative of the Latin American region during 1997. They found that the spillover effect started on July $15^{\text {th }}$ with the Thailand currency crisis. However, this spillover was not clearly observed until after October $23^{\text {rd }}$ (the Hong Kong crash). In a recent study, $\mathrm{Ng}$ (2000) found significant spillover effects from Japan and the US stock market on six Pacific-Basin markets, namely those of Hong Kong, Korea, Malaysia, Singapore, Taiwan and Thailand. In order to study international transmission effects of this type, a new testing technique based on the wavelet transform, was developed by Lee (2002) and applied to three developed markets (US, Germany and Japan) and two emerging markets in the MENA ${ }^{4}$ region, namely Egypt and Turkey. The author reported that movements from the developed markets affected the developing markets but not vice versa.

In addition, Bessler and Yang (2003) employed an error correlation model and Directed Acyclic Graphs (DAG) to investigate the interdependence among nine mature markets, namely Japan, US, UK, France, Switzerland, Hong Kong, Germany, Canada and Australia. Their results showed that both changes in European and Hong Kong markets influenced the US market, while this was also affected by internal events. Moreover, Brooks and Ne-

\footnotetext{
${ }^{1}$ Generalized Autoregressive Conditionally Heteroskedastic, Bollerslev (1986)

${ }^{2}$ Exponential Generalized Autoregressive Conditionally Heteroskedastic, Nelson (1991)

${ }^{3} \mathrm{CVM}$ is the Securities and Exchange Commission of Brazil

${ }^{4}$ MENA stands for the Middle East and North Africa
} 
gro (2003) studied the relationship between market co-integration and the degree to which companies operate internationally. They considered three factors (global, country-specific and industry-specific) and found that the importance of the international factor has increased since the 1980's while that of the country-specific factor has decreased on all markets.

Strong evidence of international transmission from the US and Japanese markets to Korean and Thai markets during the late 1990's was presented by Wongswan (2003), while most recently, Antoniou et al (2003) applied a VAR-EGARCH model to study the relationships among three EU markets namely Germany, France and the UK and the results showed some evidence of co-integration among those countries.

Our goal in this article is to study the evidence of global co-movements among seven stock markets, three in Europe (namely Irish, UK, and Portuguese), two in the Americas (namely US, and Brazil) and two in Asia (namely Japan and Hong Kong). In particular, we are interested in whether co-movements are direct (clockwise only) or indirect, impacting of nearestneighbour (continental grouping) and whether there is global absorption of major events or large changes in worldwide markets.

The remainder of this paper is organized as follows: The method due to Lee (2002) and based on the wavelet transform is described below (Section 2 ), with data and results presented in Section 3. Conclusions and remarks form the final section.

\section{Wavelet Analysis}

The wavelet transform was introduced to solve problems associated with the Fourier transform, when dealing with non-stationary signals, or when dealing with signals which are localized in time or space as well as frequency. The Wavelet Transform (WT) has been explained in more detail, particularly in [Hijmans (1993), Bruce and Gao (1996), Gonghui et al (1999) and Lee (2002)], and we give a brief outline only in the following.

\subsection{Definition of Wavelet Transform}

The wavelet transform (WT) is a mathematical tool that can be applied to many applications such as image analysis, and signal processing. In particular, the discrete wavelet transform (DWT) is useful in dividing the data series into components of different frequency, so that each component can be studied separately to investigate the data series in depth. The wavelets have 
two types, father wavelets $\phi$ and mother wavelets $\psi$ where

$$
\int \phi(t) d t=1 \quad \text { and } \quad \int \psi(t) d t=0
$$

The smooth and low-frequency parts of a signal are described by using the father wavelets, while the detail and high-frequency components are described by the mother wavelets. The orthogonal wavelet families have four different types which are typically applied in practical analysis, namely, the haar, daublets, symmlets and coiflets.

The following is a brief synopsis of their features:

- The haar has compact support and is symmetric but, unlike the others, is not continuous.

- The daublets are continuous orthogonal wavelets with compact support.

- The symmlets have compact support and were built to be as nearly symmetric as possible.

- The coiflets were built to be nearly symmetric.

A two-scale dilation equation used to calculate the wavelets, father $\phi(t)$ and mother $\psi(t)$, is defined respectively by

$$
\begin{aligned}
\phi(t) & =\sqrt{2} \sum_{k} \ell_{k} \phi(2 t-k) \\
\psi(t) & =\sqrt{2} \sum_{k} \hbar_{k} \phi(2 t-k)
\end{aligned}
$$

where $\ell_{k}$ and $\hbar_{k}$ are the low-pass and high-pass coefficients given by

$$
\begin{aligned}
\ell_{k} & =\frac{1}{\sqrt{2}} \int \phi(t) \phi(2 t-k) d t \\
\hbar_{k} & =\frac{1}{\sqrt{2}} \int \psi(t) \phi(2 t-k) d t
\end{aligned}
$$

The orthogonal wavelet series approximation to a signal $f(t)$ is defined by

$$
f(t)=\sum_{k} s_{J, k} \phi_{J, k}(t)+\sum_{k} d_{J, k} \psi_{J, k}(t)+\ldots+\sum_{k} d_{1, k} \psi_{1, k}(t)
$$

where $J$ is the number of multiresolution levels (or scales) and $k$ ranges from 1 to the number of coefficients in the specified components (or crystals). The coefficient $s_{J, k}, d_{J, k}, \ldots, d_{1, k}$ are the wavelet transform coefficients given by

$$
\begin{aligned}
& s_{J, k}=\int \phi_{J, k}(t) f(t) d t \\
& d_{j, k}=\int \psi_{j, k}(t) f(t) d t \quad(j=1,2, \ldots, J)
\end{aligned}
$$


Their magnitude gives a measure of the contribution of the corresponding wavelet function to the signal. The functions $\phi_{J, k}(t)$ and $\psi_{j, k}(t)[j=$ $1,2, \ldots, J]$ are the approximating wavelet functions generated from $\phi$ and $\psi$ through scaling and translation as follows

$$
\begin{gathered}
\phi_{J, k}(t)=2^{\frac{-J}{2}} \phi\left(2^{-J} t-k\right)=2^{\frac{-J}{2}} \phi\left[\left(t-2^{J} k\right) / 2^{J}\right] \\
\psi_{J, k}(t)=2^{\frac{-J}{2}} \psi\left(2^{-J} t-k\right)=2^{\frac{-J}{2}} \psi\left[\left(t-2^{J} k\right) / 2^{J}\right] \quad j=1,2, \ldots, J
\end{gathered}
$$

\subsection{The Discrete Wavelet Transform (DWT)}

The discrete wavelet transform is used to compute the coefficient of the wavelet series approximation in Equation(5) for a discrete signal $f_{1}, \ldots, f_{n}$ of finite extent. The DWT maps the vector $f=\left(f_{1}, f_{2}, \ldots, f_{n}\right)^{\prime}$ to a vector of $n$ wavelet coefficients $w=\left(w_{1}, w_{2}, \ldots, w_{n}\right)^{\prime}$ which contains both the smooth coefficient $s_{J, k}$ and the detail coefficients $d_{j, k}[j=1,2, \ldots, J]$. The $s_{J, k}$ describe the underlying smooth behaviour of the signal at coarse scale $2^{J}$ while $d_{J, k}$ describe the coarse scale deviations from the smooth behaviour and $d_{J-1, k}, \ldots, d_{1, k}$ provide progressively finer scale deviations from the smooth behaviour.

In the case when $n$ divisible by $2^{J}$; there are $n / 2$ observations in $d_{1, k}$ at the finest scale $2^{1}=2$ and $n / 4$ observations in $d_{2, k}$ at the second finest scale $2^{2}=4$. Likewise, there are $n / 2^{J}$ observations in each of $d_{J, k}$ and $s_{J, k}$ where $n=n / 2+n / 4+\ldots+n / 2^{J-1}+n / 2^{J}+n / 2^{J}$.

\section{Data and Results}

\subsection{Data Description}

The data used in the following analysis consists of the daily prices of stock market indices for seven markets, [Irish (IRL), UK, Portuguese (P), US, Brazilian (BR), Japanese (JP) and Hong Kong (HK)], during the period from May 1993 to September 2003. We considered the indices ISEQ Overall (IRL), FTSE All Share (UK), PSI20 (P), S\&P500 (US), Bovespa (BR), Nikkei 225 (JP) and Hang Seng (HK) to be representative of these markets.

As each market uses its local currency for presenting the index values, we use the daily returns instead of using the daily prices where the following formula applies:

$$
\text { Daily Return }=\operatorname{Ln}\left(P_{t} / P_{t-1}\right)
$$

where 
- $P_{t}$ is the closing price of the index at time $t$.

- $P_{t-1}$ is the closing price at time $t-1$.

\section{Note:}

1. We use close-to-close returns here because the closing daily price summarizes the local and global changes and influences occurrences within the trading day which strongly affect the market.

2. Some daily observations have been deleted because the markets we studied have different holidays.In other words, if one market closed on a given day, we consider the others to close on the same day as well.

Table 1 represents the trading hours of each of these markets in GMT and shows that the Japanese together with the Hong Kong markets open first. The Japanese market closes two hours before the European (i.e. Irish, UK and Portuguese) markets open at 8:00 am, while Hong Kong closes fortyfive minutes after the European opening. The last to open are American (US and Brazilian), two hours prior to European markets closure. This implies that the starting point for market opening and closing trading hours is Asia, followed by Europe, then America.

The statistical summaries of the daily returns of all stock market indices are reported in Table 2 which shows that the sample means of the returns of all indices are positive except for those of Nikkei 225 and HSI indices. We test whether or not the skewness and kurtosis of all these series are different from zero and the results show that the returns series of ISEQ, PSI20 and FTSE indices are significantly negatively skewed. Both Bovespa and HSI indices have significant positive skewness, while S\&P500 and Nikkei225 are not significantly different from zero in this sense. However, the returns series of all indices are leptokurtic and this means that the daily returns of all indices can not be regarded as normally distributed.

Figures 1 (a) to (e) represent the daily prices of ISEQ Overall, FTSE all shares, PSI20, S\&P500 and Bovespa indices respectively. It can be seen that the prices of these indices increased in the first third of the series (1993 to 1996) corresponding to a long-term period of growth. After that, the indices became unstable due to global events such as the Hong Kong crash and Thailand crisis in 1997, "dot-com" in 2000 and September 11 ${ }^{\text {th }}$, 2001. Figures 1 (f) and (g) represent the prices of Nikkei 225 and HSI indices respectively. These demonstrate that the Japanese market is the most sensitive, possibly because companies who have shares in the Japanese stock market tend to be exposed internationally and so price index levels respond to changes both directly and indirectly. The Hong Kong market is noticeably unstable with 
a disproportionately large number of regionwide crashes (possible due to serial crises: Bird Flu, SARS, etc). The Asian financial crisis had strong direct effects on the Hong Kong market but it affected Japan's economy only weakly because only $40 \%$ of Japan's exports go to Asia. In addition, Japan was going through its own ongoing long-term economic difficulties.

From the above, there are clear indications of effects from regionwide markets as well as from worldwide markets and this picture is more detailed when we look at the results of the wavelet analysis. The energy percentages described by each wavelet component for the daily returns of seven market indices are given in Table 3 which shows that the first two high frequency crystals $\left(d_{1} \& d_{2}\right)$ explain more than $65 \%$ of the energy of these series, implying that movements are mainly caused by short-term fluctuations. Figures 2 (a) to (g) represent the discrete wavelet transform (DWT) for the daily returns of Irish, UK, Portuguese, US, Brazilian, Japanese and the Hong Kong stock market indices respectively. As mentioned, it can be seen that the first and the second wavelet components $\left(d_{1} \& d_{2}\right)$ together account for most of the variations in the returns series.

\subsection{Empirical Results}

Traditionally, we might expect strong co-movements between nearest-neighbour markets. International stock markets such as those of Ireland and the UK are closely related, while there are strong historical links between Brazilian and Portuguese markets, for example.

To investigate the inter-relationships among all seven stock markets, we estimate simple regression and reverse regression models between each pair, using three different scales. These scales are row-returns series, where these are reconstructed from the first wavelet component $\left(d_{1}\right)$ and the returns series, which are rebuilt from the first two wavelet crystals $\left(d_{1}\right.$ and $\left.d_{2}\right)$ together. Conversely, we can not apply multiple regression (using forward or backward stepwise) to study the co-movements between the stock markets directly for two main reasons: firstly, multicollinearity problems are to be expected due to the relationships between the markets, secondly, we do not know the direction or order of the spillover effects.

From the results $\left[R^{2}\right.$ and $P$-values of slopes] in Table 4 , it can be seen that there are strong co-movements between each two of the Irish, UK and Portuguese markets, while the Irish market is also influenced by the US, Japan and Hong Kong. The UK and Portuguese markets are affected by both Japan and Hong Kong, while these are impacted upon by the US and Brazilian markets. Further, the UK and Portuguese markets influence the US and Brazil. Table 4 also shows that there is co-movement between US and 
Brazilian and also between the Japanese and Hong Kong markets (nearestneighbours). No inter-relationships apparently exist between the Brazilian and either the Irish or Japanese markets, but the Brazilian market itself is significantly affected by that of Hong Kong. This implies that there is also an inner loop of "spillover effects" between Asian and American markets within the global circle, (southeast Asia to the Latin Americas). In other words, the US market affects those of Asian (Japanese and Hong Kong), which in turn impact on Brazil.

In order to get a clear picture of the historical linkage between Portuguese and Brazilian markets, we divided the whole period into three sub-periods (1993-1996, 1997-2000 and 2001-2003) and estimated the regression models between these markets using three different scales. The results are given in Table 5 and show no co-movement between Portugal and Brazil in the first period while there is significant evidence of co-movement between these markets from 1997 to 2000 . However, in the third period, the results show that there are spillover effects from the Portuguese market on to the Brazilian market, but not vice versa. This appears to provide supporting evidence for an increase in the international transmission mechanism among stock markets.

Finally, it seems clear from the values of the coefficients for each pair of regressions that directional influence is globally clockwise starting with Asian markets influencing European, European impacting on the Americas and the circle completing with American market changes impacting on those of Asian. Interestingly, only the Japanese market demonstrates mixed influences. Possible explanations can be put forward for these findings on global inter-dependence and circular spillover effects between the stock markets in different Continents as follow:

- Many firms with shares in these stock market indices are international investors.

- Different time-zones mean that trading is concluded in Asia prior to opening in Europe and similarly for Europe to America and back again to Asia. These spillover effects are noticeable on the markets which open next, but these effects become less-marked for the next global cohort.

- Global investment may imply similar actions on prices throughout. 


\section{Conclusion}

The aim of this work was to investigate the inter-relationships between seven international stock markets namely the Irish, UK, Portuguese, US, Brazilian, Japanese and Hong Kong based on daily returns. A new testing method suggested by Lee (2002) has been applied and our results show that there are significant co-movements between each European pair separately, between the US and Brazilian markets and also between the Japanese and Hong Kong markets. In addition, the indications are that there are significant spillover effects from the UK and Portuguese markets onto the US and Brazilian markets which in turn, themselves influence the Asian markets. In turn, Japan and Hong Kong impact the Europe. Finally, we can summarize our results in the following:

1. There are co-movements between regionwide markets (nearest-neighbour or intra-continental relationships).

2. There are clockwise transmissions between worldwide markets.

3. There is an increase in importance of global co-movements among worldwide stock markets, in particular since the end of the $20^{\text {th }}$ century.

4. The effect of the advent of modern communications can be seen since the mid 1990's in term of more rapid response and/or damping of effects on global patterns..

\section{REFERENCES}

1. Antoniou, A, Pescetto, G. and Violaris, A. (2003) "Modelling International Price Relationships and Interdependencies Between the Stock Index and Stock Index Futures Markets of Three EU Countries: A Multivariate Analysis", Journal of Business Finance, 30(5)\& (6), pp 645-67.

2. Bessler, D. A and Yang, J. (2003) "The Structure of Interdependence in International Stock Markets", Journal of International Money and Finance, 22, pp 261-87.

3. Brook, R. and Negro, M. D (2003) "Firm-Level Evidence on International Stock Market Comovement", International Monetary Fund, IMF Working Papers, No: 03/55, Washington, DC, USA 
4. Bruce, A. and Gao, H. Y (1996) "Applied Wavelet Analysis with SPlus", New York: Springer-Verlag.

5. CVM (1998) "International Transmission of Stock Market VolatilitySpillover Effect on Latin American Markets", the IOSCOs Emerging Markets Annual Meeting, the meeting a Conference on Management of Volatility in Turbulent Markets, Kuala Lumpur, Malaysia, May 1998.

6. Eun, C. S. and Shim, S. (1989) "International Transmission of Stock Market Movements", Journal of Finance and Quantitative Analysis, 24(2), pp 241-56.

7. Francis, B. B. and Leachman, L. L. (1998) "Superexogeneity and the Dynamic Linkages among International Equity Markets", Journal of International Money and Finance, 17, pp 475-92.

8. Gonghui, Z., Starck, J. L., Campbell, J. and Murtagh, F. (1999) "The Wavelet Transform for Filtering Financial Dtat Stream", (available from strule.cs.qub.ac.uk/ gzheng/financial-engineering/finpapermay99.html).

9. Hijmans, H. E. (1993)"Discrete Wavelet and Multiresolution Analysis", Wavelets: An Elementery Treatment of Theory and Application, Tom, H. Koornwinder(ed.), (Singapore: World Scientific Publishing Co. Pte.Ltd), 49-79.

10. Kim, S. W. and Rogers, J. H. (1995) "International Stock Price Spillovers and Market Liberalization: Evidence From Korea, Japan, and the United States", Journal of Empirical Finance, 2, pp 117-33.

11. Lee, H. S(2002) "International Transmission of Stock Market Movements: A Wavelet Analysis on MENA Stock Market", Economic Research Forum, ERF Eighth Annual Conference, Cairo, Egypt, January 2002 .

12. Lin, W, Engle, R. F. and Ito, T. (1994) "Do Bulls and Bears Move Across Borders? International Transmission of Stock Returns and Volatility", The Review of Financial Studies, 7(3), pp 507-38.

13. Ng, A. (2000) "Volatility Spillover Effect from Japan and the US to the Pacific-Basin", Journal of International Money nad Finance, 19, pp 207-33.

14. Wongswan, J. (2003) "Transmission of Information Across International Equity Markets", International Finance Discussion Papers, 759, Board of Governors of the Federal Reserve System. 
Table 1: Trading Hours for each markets in GMT.

\begin{tabular}{|l|l|l|l|}
\hline Continental $\downarrow$ & Markets $\downarrow$ & Open & Close \\
\hline Asia & & & \\
\hline & Japanese & $0: 00 \mathrm{am}$ & $6: 00 \mathrm{am}$ \\
\hline & Hong Kong & $1: 45 \mathrm{am}$ & $8: 45 \mathrm{am}$ \\
\hline Europe & & & \\
\hline & UK & $8: 00 \mathrm{am}$ & $4: 30 \mathrm{pm}$ \\
\hline & Irish & $7: 50 \mathrm{am}$ & $4: 30 \mathrm{pm}$ \\
\hline & Portuguese & $8: 00 \mathrm{am}$ & $4: 30 \mathrm{pm}$ \\
\hline America & & & \\
\hline & US & $2: 30 \mathrm{pm}$ & $9: 15 \mathrm{pm}$ \\
\hline & Brazilian & $2: 00 \mathrm{pm}$ & $8: 45 \mathrm{pm}$ \\
\hline
\end{tabular}

Table 2: Descriptive statistics of the daily returns of the stock markets indices series.

\begin{tabular}{|l|c|c|c|c|c|c|c|}
\hline $\begin{array}{l}\text { Index } \rightarrow \\
\text { Measure } \downarrow\end{array}$ & ISEQ & PSI20 & FTSE & S\&P500 & Bovespa & Nikkei225 & HSI \\
\hline Mean & 0.0004 & 0.0001 & 0.0003 & 0.0003 & 0.0024 & -0.0003 & -0.0001 \\
\hline Std.Dev & 0.0102 & 0.0099 & 0.0109 & 0.0112 & 0.02823 & 0.0147 & 0.0179 \\
\hline Min & -0.0757 & -0.051 & -0.071 & -0.070 & -0.172 & -0.072 & -0.147 \\
\hline Max & 0.0483 & 0.0509 & 0.0694 & 0.0557 & 0.2883 & 0.0765 & 0.1725 \\
\hline Skewness & $-0.549^{* *}$ & $-0.226^{* *}$ & $-0.355^{* *}$ & -0.073 & $0.5780^{* *}$ & 0.078 & $0.176^{* *}$ \\
\hline Kurtosis & $4.465^{* *}$ & $2.816^{* *}$ & $5.061^{* *}$ & $3.072^{* *}$ & $8.631^{* *}$ & $2.053^{* *}$ & $9.242^{* *}$ \\
\hline
\end{tabular}

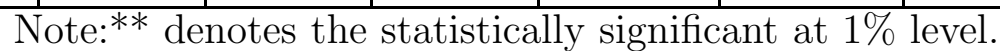

Table 3: Percentages of energy by wavelet crystals for the daily returns of indices series.

indices series.
\begin{tabular}{|c|c|c|c|c|c|c|c|}
\hline $\begin{array}{c}\text { Index } \rightarrow \\
\text { W.Crystals } \downarrow\end{array}$ & ISEQ & FTSE & PSI20 & S\&P500 & Bovespa & Nikkei225 & HSI \\
\hline$d_{1}$ & 0.443 & 0.467 & 0.440 & 0.448 & 0.476 & 0.534 & 0.515 \\
\hline$d_{2}$ & 0.246 & 0.260 & 0.262 & 0.241 & 0.234 & 0.240 & 0.230 \\
\hline$d_{3}$ & 0.145 & 0.161 & 0.122 & 0.161 & 0.143 & 0.117 & 0.133 \\
\hline$d_{4}$ & 0.072 & 0.048 & 0.081 & 0.053 & 0.046 & 0.051 & 0.055 \\
\hline$d_{5}$ & 0.040 & 0.032 & 0.034 & 0.032 & 0.025 & 0.031 & 0.038 \\
\hline$d_{6}$ & 0.031 & 0.018 & 0.026 & 0.013 & 0.019 & 0.015 & 0.016 \\
\hline$s_{6}$ & 0.022 & 0.014 & 0.035 & 0.012 & 0.057 & 0.013 & 0.014 \\
\hline
\end{tabular}


Table 4: Regression Analysis between the daily returns of each pair of the seven stock market indices.

\begin{tabular}{|l|l|l|c|l|l|c|}
\hline Regression $\rightarrow$ & \multicolumn{9}{|c|}{ 1: IRL vs. UK } \\
& \multicolumn{2}{|c|}{$M_{t}{ }^{I R L}$ on } & \multicolumn{1}{l|}{$M_{t}{ }^{U K}$} & \multicolumn{2}{l|}{$M_{t}{ }^{U K}$ on } & \multicolumn{2}{l|}{$M_{t}^{I R L}$} \\
\hline Scales $\downarrow$ & Constant & Slope & $R^{2}$ & Constant & Slope & $R^{2}$ \\
\hline Return & $3.80 \mathrm{E}-04$ & 0.578 & 0.323 & $-1.74 \mathrm{E}-04$ & 0.559 & 0.323 \\
& $(0.029)$ & $(0.000)$ & & $(0.310)$ & $(0.000)$ & \\
\hline Return.D1 & $1.13 \mathrm{E}-04$ & 0.467 & 0.222 & $-1.41 \mathrm{E}-04$ & 0.477 & 0.222 \\
& $(0.391)$ & $(0.000)$ & & $(0.289)$ & $(0.000)$ & \\
\hline Return.D1.2 & $1.49 \mathrm{E}-05$ & 0.495 & 0.251 & $-4.32 \mathrm{E}-05$ & 0.508 & 0.251 \\
& $(0.951)$ & $(0.000)$ & & $(0.864)$ & $(0.000)$ & \\
\hline
\end{tabular}

2: IRL vs. $\mathrm{P}$

\begin{tabular}{|l|l|l|c|l|l|c|}
\hline Regression $\rightarrow$ & \multicolumn{4}{|c|}{} & \multicolumn{3}{|c|}{$M_{t}^{P}$ on } & \multicolumn{2}{|c|}{$M_{t}^{I R L}$} \\
& $M_{t}{ }^{I R L}$ on & \multicolumn{1}{|c|}{$M_{t}{ }^{P}$} & \multicolumn{1}{|c|}{} \\
\hline Scales $\downarrow$ & Constant & Slope & $R^{2}$ & Constant & Slope & $R^{2}$ \\
\hline Return & $3.06 \mathrm{E}-04$ & 0.343 & 0.135 & $1.50 \mathrm{E}-04$ & 0.394 & 0.135 \\
& $(0.119)$ & $(0.000)$ & & $(0.477)$ & $(0.000)$ & \\
\hline Return.D1 & $2.64 \mathrm{E}-05$ & 0.359 & 0.145 & $7.06 \mathrm{E}-05$ & 0.405 & 0.145 \\
& $(0.849)$ & $(0.000)$ & & $(0.631)$ & $(0.000)$ & \\
\hline Return.D1.2 & $1.97 \mathrm{E}-05$ & 0.385 & 0.165 & $-6.98 \mathrm{E}-05$ & 0.420 & 0.165 \\
& $(0.940)$ & $(0.000)$ & & $(0.801)$ & $(0.000)$ & \\
\hline
\end{tabular}

3: IRL vs. US

\begin{tabular}{|l|l|l|c|l|l|c|}
\hline Regression $\rightarrow$ & \multicolumn{3}{|c|}{} & \multicolumn{3}{|c|}{$M_{t}^{U S}$ on } \\
& \multicolumn{2}{|c|}{$M_{t}^{I R L}$ on } & \multicolumn{2}{l|}{$M_{t-1}{ }^{I R L}$} & \\
\hline Scales $\downarrow$ & Constant & Slope & $R^{2}$ & Constant & Slope & $R^{2}$ \\
\hline Return & $3.11 \mathrm{E}-04$ & 0.328 & 0.129 & $1.99 \mathrm{E}-04$ & 0.255 & 0.053 \\
& $(0.114)$ & $(0.000)$ & & $(0.378)$ & $(0.000)$ & \\
\hline Return.D1 & $7.06 \mathrm{E}-05$ & 0.154 & 0.031 & $2.12 \mathrm{E}-05$ & $7.79 \mathrm{E}-04$ & 0.004 \\
& 0.632 & $(0.000)$ & & $(0.900)$ & $(0.001)$ & \\
\hline Return.D1.2 & $-2.37 \mathrm{E}-05$ & 0.217 & 0.024 & $-9.02 \mathrm{E}-05$ & $7.75 \mathrm{E}-02$ & 0.004 \\
& $(0.933)$ & $(0.000)$ & & $(0.785)$ & $(0.001)$ & \\
\hline
\end{tabular}

4: IRL vs. BR

\begin{tabular}{|c|c|c|c|c|c|c|}
\hline Regression $\rightarrow$ & $M_{t}^{I R L}$ on & $M_{t-1} B R$ & & $M_{t}^{B R}$ on & $M_{t}^{I R L}$ & \\
\hline Scales $\downarrow$ & Constant & Slope & $R^{2}$ & Constant & Slope & $R^{2}$ \\
\hline Return & $\begin{array}{l}2.79 \mathrm{E}-04 \\
(0.184)\end{array}$ & $\begin{array}{l}5.47 \mathrm{E}-02 \\
(0.000)\end{array}$ & 0.023 & $\begin{array}{l}2.31 \mathrm{E}-03 \\
(0.000)\end{array}$ & $\begin{array}{l}0.361 \\
(0.000) \\
\end{array}$ & 0.016 \\
\hline Return.D1 & $\begin{array}{l}6.06 \mathrm{E}-05 \\
(0.685) \\
\end{array}$ & $\begin{array}{l}1.67 \mathrm{E}-02 \\
(0.036)\end{array}$ & 0.001 & $\begin{array}{l}-3.70 \mathrm{E}-05 \\
(0.928) \\
\end{array}$ & $\begin{array}{l}0.254 \\
(0.000) \\
\end{array}$ & 0.008 \\
\hline Ret & $\begin{array}{l}-8.65 \mathrm{E}-06 \\
(0.976)\end{array}$ & $\begin{array}{l}2.69 \mathrm{E}-02 \\
(0.023)\end{array}$ & 0.002 & $\begin{array}{l}-1.98 \mathrm{E}-04 \\
(0.692)\end{array}$ & $\begin{array}{l}0.122 \\
(0.001)\end{array}$ & 0.004 \\
\hline
\end{tabular}


5: IRL vs. JP

\begin{tabular}{|c|c|c|c|c|c|c|}
\hline \multirow{2}{*}{$\begin{array}{l}\text { Regression } \rightarrow \\
\text { Scales } \downarrow\end{array}$} & \multicolumn{3}{|c|}{$M_{t}^{I R L}$ on $\quad M_{t}^{J P}$} & \multicolumn{3}{|c|}{$M_{t}^{J P}$ on $\quad M_{t-1}^{I R L}$} \\
\hline & Constant & Slope & $\overline{R^{2}}$ & Constant & Slope & $R^{2}$ \\
\hline Return & $\begin{array}{l}4.77 \mathrm{E}-04 \\
(0.019)\end{array}$ & $\begin{array}{l}0.181 \\
(0.000)\end{array}$ & 0.068 & $\begin{array}{l}-4.06 \mathrm{E}-04 \\
(0.183)\end{array}$ & $\begin{array}{l}0.127 \\
(0.000)\end{array}$ & 0.007 \\
\hline Return.D1 & $\begin{array}{l}5.16 \mathrm{E}-05 \\
(0.723)\end{array}$ & $\begin{array}{l}0.147 \\
(0.000)\end{array}$ & 0.052 & $\begin{array}{l}6.76 \mathrm{E}-05 \\
(0.771)\end{array}$ & $\begin{array}{l}-8.18 \mathrm{E}-02 \\
(0.010)\end{array}$ & 0.002 \\
\hline Return.D1.2 & $\begin{array}{l}-1.18 \mathrm{E}-05 \\
(0.996)\end{array}$ & $\begin{array}{l}0.147 \\
(0.000)\end{array}$ & 0.054 & $\begin{array}{l}2.61 \mathrm{E}-05 \\
(0.954)\end{array}$ & $\begin{array}{l}-0.115 \\
(0.024)\end{array}$ & 0.002 \\
\hline
\end{tabular}

6: IRL vs. HK

\begin{tabular}{|c|c|c|c|c|c|c|}
\hline Regression $\rightarrow$ & $M_{t}^{I R L}$ on & $M_{t}^{H K}$ & & $M_{t}^{H K}$ on & $M_{t-1}^{I R L}$ & \\
\hline Scales $\downarrow$ & Constant & Slope & $R^{2}$ & Constant & Slope & $R^{2}$ \\
\hline Return & $\begin{array}{l}4.19 \mathrm{E}-04 \\
(0.036)\end{array}$ & $\begin{array}{l}0.183 \\
(0.000)\end{array}$ & 0.104 & $\begin{array}{l}-4.91 \mathrm{E}-05 \\
(0.895)\end{array}$ & $\begin{array}{l}3.86 \mathrm{E}-02 \\
(0.292)\end{array}$ & 0.000 \\
\hline Return.D1 & $\begin{array}{l}4.88 \mathrm{E}-05 \\
(0.731)\end{array}$ & $\begin{array}{l}0.170 \\
(0.000)\end{array}$ & 0.097 & $\begin{array}{l}9.54 \mathrm{E}-05 \\
(0.724)\end{array}$ & $\begin{array}{c}-0.302 \\
(0.000)\end{array}$ & 0.028 \\
\hline Return.D1.2 & $\begin{array}{l}-3.13 \mathrm{E}-06 \\
(0.991)\end{array}$ & $\begin{array}{l}0.182 \\
(0.000)\end{array}$ & 0.117 & $\begin{array}{l}-1.48 \mathrm{E}-05 \\
(0.978)\end{array}$ & $\begin{array}{l}-0.396 \\
(0.000)\end{array}$ & 0.018 \\
\hline
\end{tabular}

7: UK vs. $\mathrm{P}$

\begin{tabular}{|c|c|c|c|c|c|c|}
\hline Regression $\rightarrow$ & $M_{t}^{U K}$ on & $M_{t}^{P}$ & & $M_{t}^{P}$ on & $M_{t}^{U K}$ & \\
\hline Scales $\downarrow$ & Constant & Slope & $\overline{R^{2}}$ & Constant & Slope & $\overline{R^{2}}$ \\
\hline Return & $\begin{array}{l}-7.95 \mathrm{E}-05 \\
(0.663)\end{array}$ & $\begin{array}{l}0.438 \\
(0.000)\end{array}$ & 0.228 & $\begin{array}{l}2.83 \mathrm{E}-04 \\
(0.155)\end{array}$ & $\begin{array}{l}0.521 \\
(0.000)\end{array}$ & 0.228 \\
\hline Return.D1 & $\begin{array}{l}-1.55 \mathrm{E}-04 \\
(0.243)\end{array}$ & $\begin{array}{l}0.451 \\
(0.000)\end{array}$ & 0.224 & $\begin{array}{l}1.51 \mathrm{E}-04 \\
(0.280)\end{array}$ & $\begin{array}{l}0.498 \\
(0.000)\end{array}$ & 0.224 \\
\hline Return.D1.2 & $\begin{array}{l}-1.22 \mathrm{E}-05 \\
(0.961)\end{array}$ & $\begin{array}{l}0.481 \\
(0.000)\end{array}$ & 0.252 & $\begin{array}{l}-4.86 \mathrm{E}-05 \\
(0.853)\end{array}$ & $\begin{array}{l}0.524 \\
(0.000)\end{array}$ & 0.252 \\
\hline
\end{tabular}

8: UK vs. US

\begin{tabular}{|l|l|l|c|l|l|c|}
\hline Regression $\rightarrow$ & \multicolumn{3}{|c|}{ 8: UK vs. US } & \multicolumn{2}{|c|}{$M_{t}^{U S}$ on } & \multicolumn{2}{c|}{$M_{t}^{U K}$} \\
& \multicolumn{2}{|c|}{$M_{t}^{U K}$ on $M_{t-1}{ }^{U S}$} & \multicolumn{1}{l|}{${ }^{2}$} & \\
\hline Scales $\downarrow$ & Constant & Slope & $R^{2}$ & Constant & Slope & $R^{2}$ \\
\hline Return & $-2.03 \mathrm{E}-05$ & 0.251 & 0.078 & $2.78 \mathrm{E}-04$ & 0.473 & 0.178 \\
& $(0.919)$ & $(0.000)$ & & $(0.188)$ & $(0.000)$ & \\
\hline Return.D1 & $-1.12 \mathrm{E}-04$ & $1.13 \mathrm{E}-02$ & 0.000 & $5.54 \mathrm{E}-05$ & 0.262 & 0.054 \\
& $(0.468)$ & $(0.537)$ & & $(0.736)$ & $(0.000)$ & \\
\hline Return.D1.2 & $-4.73 \mathrm{E}-05$ & $-3.46 \mathrm{E}-03$ & 0.000 & $-7.70 \mathrm{E}-05$ & 0.292 & 0.065 \\
& $(0.871)$ & $(0.906)$ & & $(0.810)$ & $(0.000)$ & \\
\hline
\end{tabular}


9: UK vs. BR

\begin{tabular}{|c|c|c|c|c|c|c|}
\hline Regression $\rightarrow$ & $M_{t}^{U K}$ on & $M_{t-1}{ }^{B R}$ & & $M_{t}^{B R}$ on & $M_{t}^{U K}$ & \\
\hline Scales $\downarrow$ & Constant & Slope & $R^{2}$ & Constant & Slope & $R^{2}$ \\
\hline Return & $\begin{array}{l}-3.38 \mathrm{E}-05 \\
(0.870) \\
\end{array}$ & $\begin{array}{l}3.71 \mathrm{E}-02 \\
(0.000)\end{array}$ & 0.011 & $\begin{array}{l}2.42 \mathrm{E}-03 \\
(0.000)\end{array}$ & $\begin{array}{l}0.659 \\
(0.000)\end{array}$ & 0.054 \\
\hline Return.D1 & $\begin{array}{l}-1.12 \mathrm{E}-04 \\
(0.457) \\
\end{array}$ & $\begin{array}{l}-1.53 \mathrm{E}-02 \\
(0.057) \\
\end{array}$ & 0.001 & $\begin{array}{l}3.49 \mathrm{E}-05 \\
(0.931)\end{array}$ & $\begin{array}{l}0.503 \\
(0.000) \\
\end{array}$ & 0.034 \\
\hline Return.D1.2 & $\begin{array}{l}-4.76 \mathrm{E}-05 \\
(0.870)\end{array}$ & $\begin{array}{l}-1.38 \mathrm{E}-02 \\
(0.250)\end{array}$ & 0.000 & $\begin{array}{l}-1.86 \mathrm{E}-04 \\
(0.707)\end{array}$ & $\begin{array}{l}0.265 \\
(0.000)\end{array}$ & 0.023 \\
\hline
\end{tabular}

\begin{tabular}{|l|l|l|c|l|l|c|}
\hline Regression $\rightarrow$ & \multicolumn{9}{|c|}{ 10: UK vs. JP } \\
& \multicolumn{2}{|c|}{$M_{t}^{U K}$ on $M_{t}^{J P}$} & \multicolumn{1}{c|}{$M_{t}^{J P}$ on } & \multicolumn{1}{c|}{$M_{t-1}{ }^{J K}$} & \\
\hline Scales $\downarrow$ & Constant & Slope & $R^{2}$ & Constant & Slope & $R^{2}$ \\
\hline Return & $1.21 \mathrm{E}-04$ & 0.178 & 0.068 & $-3.72 \mathrm{E}-04$ & 0.292 & 0.039 \\
& $(0.548)$ & $(0.000)$ & & $(0.214)$ & $(0.000)$ & \\
\hline Return.D1 & $-1.19 \mathrm{E}-04$ & 0.113 & 0.030 & $5.73 \mathrm{E}-05$ & $9.20 \mathrm{E}-02$ & 0.003 \\
& $(0.423)$ & $(0.000)$ & & $(0.805)$ & $(0.003)$ & \\
\hline Return.D1.2 & $-5.03 \mathrm{E}-05$ & 0.124 & 0.037 & $2.42 \mathrm{E}-05$ & 0.119 & 0.002 \\
& $(0.860)$ & $(0.000)$ & & $(0.957)$ & $(0.018)$ & \\
\hline
\end{tabular}

\begin{tabular}{|c|c|c|c|c|c|c|}
\hline \multicolumn{7}{|c|}{ 11: UK vs. H } \\
\hline Regression $\rightarrow$ & $M_{t}^{U K}$ on & $M_{t}^{H K}$ & & $M_{t}^{H K}$ on & $M_{t-1} U K$ & \\
\hline Scales $\downarrow$ & Constant & Slope & $\overline{R^{2}}$ & Constant & Slope & $R^{2}$ \\
\hline Return & $\begin{array}{l}6.37 \mathrm{E}-05 \\
(0.745)\end{array}$ & $\begin{array}{l}0.187 \\
(0.000)\end{array}$ & 0.112 & $\begin{array}{l}-5.60 \mathrm{E}-05 \\
(0.879)\end{array}$ & $\begin{array}{l}0.349 \\
(0.000)\end{array}$ & 0.038 \\
\hline Return.D1 & $\begin{array}{l}-1.22 \mathrm{E}-04 \\
(0.407) \\
\end{array}$ & $\begin{array}{l}0.133 \\
(0.000) \\
\end{array}$ & 0.058 & $\begin{array}{l}7.07 \mathrm{E}-05 \\
(0.796) \\
\end{array}$ & $\begin{array}{l}-4.37 \mathrm{E}-02 \\
(0.239) \\
\end{array}$ & 0.000 \\
\hline Return.D1.2 & $\begin{array}{l}-4.39 \mathrm{E}-05 \\
(0.877)\end{array}$ & $\begin{array}{l}0.122 \\
(0.000)\end{array}$ & 0.050 & $\begin{array}{l}-3.17 \mathrm{E}-05 \\
(0.953)\end{array}$ & $\begin{array}{l}-6.80 \mathrm{E}-02 \\
(0.257)\end{array}$ & 0.000 \\
\hline
\end{tabular}

12: P vs. US

\begin{tabular}{|c|c|c|c|c|c|c|}
\hline Regression $\rightarrow$ & $M_{t}^{P}$ on & $M_{t-1} U S$ & & $M_{t}^{U S}$ on & $M_{t}^{P}$ & \\
\hline Scales $\downarrow$ & Constant & Slope & $R^{2}$ & Constant & Slope & $R^{2}$ \\
\hline Return & $\begin{array}{l}2.59 \mathrm{E}-04 \\
(0.246)\end{array}$ & $\begin{array}{l}0.174 \\
(0.000)\end{array}$ & 0.031 & $\begin{array}{l}2.21 \mathrm{E}-04 \\
(0.323)\end{array}$ & $\begin{array}{l}0.265 \\
(0.000)\end{array}$ & 0.067 \\
\hline Return.D1 & $\begin{array}{l}9.76 \mathrm{E}-05 \\
(0.539)\end{array}$ & $\begin{array}{l}3.69 \mathrm{E}-02 \\
(0.055)\end{array}$ & 0.001 & $\begin{array}{l}9.36 \mathrm{E}-06 \\
(0.955)\end{array}$ & $\begin{array}{l}0.174 \\
(0.000)\end{array}$ & $\overline{0.026}$ \\
\hline Return.D1.2 & $\begin{array}{l}-7.64 \mathrm{E}-05 \\
(0.801)\end{array}$ & $\begin{array}{l}4.11 \mathrm{E}-02 \\
(0.178)\end{array}$ & 0.000 & $\begin{array}{l}-7.62 \mathrm{E}-05 \\
(0.815)\end{array}$ & $\begin{array}{l}0.199 \\
(0.000)\end{array}$ & 0.033 \\
\hline
\end{tabular}


13: $\mathrm{P}$ vs. $\mathrm{BR}$

\begin{tabular}{|c|c|c|c|c|c|c|}
\hline Regression $\rightarrow$ & $M_{t}^{P}$ on & $M_{t-1}^{B R}$ & & $M_{t}^{B R}$ on & $M_{t}^{P}$ & \\
\hline Scales $\downarrow$ & Constant & Slope & $R^{2}$ & Constant & Slope & $R^{2}$ \\
\hline Return & $\begin{array}{l}1.94 \mathrm{E}-04 \\
(0.391)\end{array}$ & $\begin{array}{l}4.94 \mathrm{E}-02 \\
(0.000)\end{array}$ & 0.015 & $\begin{array}{l}2.30 \mathrm{E}-05 \\
(0.000)\end{array}$ & $\begin{array}{l}0.489 \\
(0.000)\end{array}$ & 0.035 \\
\hline Return.D1 & $\begin{array}{l}9.52 \mathrm{E}-05 \\
(0.549)\end{array}$ & $\begin{array}{l}9.93 \mathrm{E}-03 \\
(0.240)\end{array}$ & 0.000 & $\begin{array}{l}-5.20 \mathrm{E}-05 \\
(0.899)\end{array}$ & $\begin{array}{l}0.319 \\
(0.000)\end{array}$ & 0.015 \\
\hline Return.D1.2 & $\begin{array}{l}-7.35 \mathrm{E}-05 \\
(0.809)\end{array}$ & $\begin{array}{l}6.73 \mathrm{E}-03 \\
(0.590)\end{array}$ & 0.000 & $\begin{array}{l}-1.85 \mathrm{E}-04 \\
(0.770)\end{array}$ & $\begin{array}{l}0.188 \\
(0.000)\end{array}$ & 0.013 \\
\hline
\end{tabular}

\begin{tabular}{|l|l|l|c|l|l|c|}
\hline \multicolumn{7}{|c}{$14: \mathrm{P}$ vs. JP } \\
\hline Regression $\rightarrow$ & \multicolumn{2}{|c|}{$M_{t}{ }^{J P}$} & \multicolumn{1}{|c|}{$M_{t}{ }^{J P}$ on } & \multicolumn{1}{c|}{$M_{t-1}{ }^{P}$} & \\
\hline Scales $\downarrow$ & Constant & Slope & $R^{2}$ & Constant & Slope & $R^{2}$ \\
\hline Return & $3.60 \mathrm{E}-04$ & 0.134 & 0.032 & $-4.00 \mathrm{E}-04$ & 0.150 & 0.012 \\
& $(0.1060$ & $(0.000)$ & & $(0.188)$ & $(0.000)$ & \\
\hline Return.D1 & $8.83 \mathrm{E}-05$ & 0.113 & 0.027 & $5.95 \mathrm{E}-05$ & $4.06 \mathrm{E}-02$ & 0.000 \\
& $(0.573)$ & $(0.000)$ & & $(0.798)$ & $(0.203)$ & \\
\hline Return.D1.2 & $-7.62 \mathrm{E}-05$ & 0.125 & 0.034 & $1.32 \mathrm{E}-05$ & $6.50 \mathrm{E}-02$ & 0.000 \\
& $(0.798)$ & $(0.000)$ & & $(0.977)$ & $(0.174)$ & \\
\hline
\end{tabular}

\begin{tabular}{|c|c|c|c|c|c|c|}
\hline \multicolumn{7}{|c|}{ 5: $\mathrm{P}$ vs. $\mathrm{HK}$} \\
\hline Scales $\downarrow$ & Constant & Slope & $\overline{R^{2}}$ & Constant & Slope & $\overline{R^{2}}$ \\
\hline Return & $\begin{array}{l}3.19 \mathrm{E}-04 \\
(0.144)\end{array}$ & $\begin{array}{l}0.168 \\
(0.0000\end{array}$ & 0.076 & $\begin{array}{l}-7.77 \mathrm{E}-05 \\
(0.834)\end{array}$ & $\begin{array}{l}0.143 \\
(0.000)\end{array}$ & 0.007 \\
\hline Return.D1 & $\begin{array}{l}8.53 \mathrm{E}-05 \\
(0.560)\end{array}$ & $\begin{array}{l}0.143 \\
(0.000)\end{array}$ & 0.060 & $\begin{array}{l}7.29 \mathrm{E}-05 \\
(0.789)\end{array}$ & $\begin{array}{c}-0.141 \\
(0.000)\end{array}$ & 0.006 \\
\hline Return.D1.2 & $\begin{array}{l}-6.90 \mathrm{E}-05 \\
(0.814)\end{array}$ & $\begin{array}{l}0.150 \\
(0.000)\end{array}$ & 0.070 & $\begin{array}{l}-1.34 \mathrm{E}-02 \\
(0.980)\end{array}$ & $\begin{array}{c}-0.130 \\
(0.023)\end{array}$ & 0.002 \\
\hline
\end{tabular}

16: US vs. BR

\begin{tabular}{|c|c|c|c|c|c|c|}
\hline Regression $\longrightarrow$ & $M_{t}^{U S}$ on & $M_{t}^{B R}$ & & $M_{t}^{B R}$ on & $M_{t}^{B R}$ & \\
\hline Scales $\downarrow$ & Constant & Slope & $R^{2}$ & Constant & Slope & $R^{2}$ \\
\hline Return & $\begin{array}{l}-1.85 \mathrm{E}-05 \\
(0.933)\end{array}$ & $\begin{array}{l}0.132 \\
(0.000)\end{array}$ & 0.110 & $\begin{array}{l}2.20 \mathrm{E}-03 \\
(0.000)\end{array}$ & $\begin{array}{l}0.841 \\
(0.000)\end{array}$ & 0.110 \\
\hline Return.D1 & $\begin{array}{l}2.84 \mathrm{E}-05 \\
(0.861)\end{array}$ & $\begin{array}{l}0.114 \\
(0.000)\end{array}$ & 0.076 & $\begin{array}{l}-3.91 \mathrm{E}-05 \\
(0.921)\end{array}$ & $\begin{array}{l}0.674 \\
(0.000)\end{array}$ & 0.077 \\
\hline Return.D1.2 & $\begin{array}{l}-6.03 \mathrm{E}-05 \\
(0.852)\end{array}$ & $\begin{array}{l}0.154 \\
(0.000)\end{array}$ & 0.054 & $\begin{array}{l}-1.67 \mathrm{E}-04 \\
(0.732)\end{array}$ & $\begin{array}{l}0.351 \\
(0.000)\end{array}$ & 0.054 \\
\hline
\end{tabular}




\begin{tabular}{|c|c|c|c|c|c|c|}
\hline Regression $\rightarrow$ & $M_{t}^{U S}$ on & $M_{t}^{J P}$ & & $M_{t}^{J P}$ on & $M_{t-1} U S$ & \\
\hline Scales $\downarrow$ & Constant & Slope & $R^{2}$ & Constant & Slope & $R^{2}$ \\
\hline Return & $\begin{array}{l}3.31 \mathrm{E}-04 \\
(0.152)\end{array}$ & $\begin{array}{l}7.45 \mathrm{E}-02 \\
(0.000)\end{array}$ & 0.009 & $\begin{array}{l}-4.77 \mathrm{E}-04 \\
(0.101)\end{array}$ & $\begin{array}{l}0.401 \\
(0.000)\end{array}$ & 0.092 \\
\hline Return.D1 & $\begin{array}{l}2.92 \mathrm{E}-05 \\
(0.862)\end{array}$ & $\begin{array}{l}-5.37 \mathrm{E}-02 \\
(0.000)\end{array}$ & 0.005 & $\begin{array}{l}8.15 \mathrm{E}-05 \\
(0.718)\end{array}$ & $\begin{array}{l}0.322 \\
(0.000)\end{array}$ & 0.056 \\
\hline Return.D1.2 & $\begin{array}{l}-8.97 \mathrm{E}-05 \\
(0.991)\end{array}$ & $\begin{array}{l}-5.10 \mathrm{E}-02 \\
(0.786)\end{array}$ & 0.004 & $\begin{array}{l}-8.93 \mathrm{E}-06 \\
(0.994)\end{array}$ & $\begin{array}{l}0.441 \\
(0.000)\end{array}$ & 0.041 \\
\hline
\end{tabular}

\begin{tabular}{|c|c|c|c|c|c|c|}
\hline Regression $\rightarrow$ & $M_{t}^{U S}$ on & $M_{t}^{H K}$ & & $M_{t}^{H K}$ on & $M_{t-1} U S$ & \\
\hline Scales $\downarrow$ & Constant & Slope & $\overline{R^{2}}$ & Constant & Slope & $R^{2}$ \\
\hline Return & $\begin{array}{l}3.07 \mathrm{E}-04 \\
(0.184)\end{array}$ & $\begin{array}{l}6.78 \mathrm{E}-02 \\
(0.000)\end{array}$ & 0.011 & $\begin{array}{l}-2.01 \mathrm{E}-04 \\
(0.566)\end{array}$ & $\begin{array}{l}0.541 \\
(0.000)\end{array}$ & 0.114 \\
\hline Return.D1 & $\begin{array}{l}2.97 \mathrm{E}-05 \\
(0.860)\end{array}$ & $\begin{array}{l}-5.50 \mathrm{E}-02 \\
(0.000)\end{array}$ & 0.007 & $\begin{array}{l}9.62 \mathrm{E}-05 \\
(0.719)\end{array}$ & $\begin{array}{l}0.401 \\
(0.000)\end{array}$ & 0.063 \\
\hline Return.D1.2 & $\begin{array}{l}-9.25 \mathrm{E}-05 \\
(0.779)\end{array}$ & $\begin{array}{l}-5.50 \mathrm{E}-02 \\
(0.000)\end{array}$ & 0.008 & $\begin{array}{l}-7.39 \mathrm{E}-05 \\
(0.888)\end{array}$ & $\begin{array}{l}0.630 \\
(0.000)\end{array}$ & 0.058 \\
\hline
\end{tabular}

\begin{tabular}{|l|l|l|c|l|l|c|}
\hline \multicolumn{9}{|c|}{ 19: BR vs. JP } \\
\hline Regression $\rightarrow$ & \multicolumn{2}{|c|}{$M_{t}{ }^{J P}$} & \multicolumn{2}{|c|}{$M_{t}{ }^{J P}$ on } & \multicolumn{2}{l|}{$M_{t-1}{ }^{B R}$} \\
\hline Scales $\downarrow$ & Constant & Slope & $R^{2}$ & Constant & Slope & $R^{2}$ \\
\hline Return & $-5.34 \mathrm{E}-04$ & $7.33 \mathrm{E}-02$ & 0.019 & $2.51 \mathrm{E}-03$ & 0.154 & 0.006 \\
& $(0.079)$ & $(0.000)$ & & $(0.000)$ & $(0.000)$ & \\
\hline Return.D1 & $6.06 \mathrm{E}-05$ & $5.79 \mathrm{E}-02$ & 0.009 & $-2.31 \mathrm{E}-05$ & $2.49 \mathrm{E}-02$ & 0.000 \\
& $(0.794)$ & $(0.000)$ & & $(0.955)$ & $(0.498)$ & \\
\hline Return.D1.2 & $2.16 \mathrm{E}-05$ & $7.22 \mathrm{E}-02$ & 0.006 & $-1.99 \mathrm{E}-04$ & $4.43 \mathrm{E}-03$ & 0.000 \\
& $(0.962)$ & $(0.000)$ & & $(0.691)$ & $(0.848)$ & \\
\hline
\end{tabular}

\begin{tabular}{|l|l|l|c|l|l|c|}
\hline Regression $\rightarrow$ & \multicolumn{9}{|c|}{ 20: BR vs. HK } \\
& \multicolumn{2}{|c|}{$M_{t}{ }^{B R}$ on $M_{t}{ }^{H K}$} & \multicolumn{2}{|c|}{$M_{t}{ }^{H K}$ on } & \multicolumn{2}{c|}{$M_{t-1}{ }^{B R}$} \\
\hline Scales $\downarrow$ & Constant & Slope & $R^{2}$ & Constant & Slope & $R^{2}$ \\
\hline Return & $-3.30 \mathrm{E}-04$ & 0.121 & 0.036 & $2.46 \mathrm{E}-03$ & 0.142 & 0.008 \\
& $(0.396)$ & $(0.000)$ & & $(0.000)$ & $(0.000)$ & \\
\hline Return.D1 & $6.92 \mathrm{E}-05$ & $9.99 \mathrm{E}-02$ & 0.020 & $-2.03 \mathrm{E}-5$ & $-1.85 \mathrm{E}-2$ & 0.000 \\
& $(0.798)$ & $(0.000)$ & & $(0.961)$ & $(0.554)$ & \\
\hline Return.D1.2 & $-3.03 \mathrm{E}-05$ & 0.126 & 0.014 & $-1.99 \mathrm{E}-04$ & $-9.94 \mathrm{E}-03$ & 0.000 \\
& $(0.955)$ & $(0.000)$ & & $(0.691)$ & $(0.609)$ & \\
\hline
\end{tabular}




\begin{tabular}{|c|c|c|c|c|c|c|}
\hline \multirow{3}{*}{$\begin{array}{l}\text { Regression } \rightarrow \\
\text { Scales } \downarrow \\
\end{array}$} & \multicolumn{3}{|c|}{ 21: JP vs. HK } & \multirow{2}{*}{\multicolumn{3}{|c|}{$M_{t}^{H K}$ on $\quad M_{t}^{J P}$}} \\
\hline & $M_{t}^{J P}$ on & $M_{t}^{H K}$ & & & & \\
\hline & Constant & Slope & $R^{2}$ & Constant & Slope & $R^{2}$ \\
\hline Return & $\begin{array}{l}-3.44 \mathrm{E}-04 \\
(0.231)\end{array}$ & $\begin{array}{l}0.283 \\
(0.000)\end{array}$ & 0.119 & $\begin{array}{l}1.16 \mathrm{E}-04 \\
(0.741)\end{array}$ & $\begin{array}{l}0.421 \\
(0.000)\end{array}$ & 0.119 \\
\hline Return.D1 & $\begin{array}{l}4.09 \mathrm{E}-05 \\
(0.852)\end{array}$ & $\begin{array}{l}0.284 \\
(0.000)\end{array}$ & $\overline{0.111}$ & $\begin{array}{l}4.54 \mathrm{E}-05 \\
(0.860)\end{array}$ & $\begin{array}{l}0.393 \\
(0.000)\end{array}$ & 0.111 \\
\hline Return.D1.2 & $\begin{array}{l}3.06 \mathrm{E}-05 \\
(0.942)\end{array}$ & $\begin{array}{l}0.297 \\
(0.000)\end{array}$ & 0.126 & $\begin{array}{l}-3.94 \mathrm{E}-05 \\
(0.938)\end{array}$ & $\begin{array}{l}0.424 \\
(0.000)\end{array}$ & $\overline{0.126}$ \\
\hline
\end{tabular}

Table 5: Regression Analysis between Portuguese and Brazilian Markets using three different scales

\begin{tabular}{|l|l|l|c|l|l|c|}
\hline \multicolumn{7}{|c|}{ A: From 1993 To 1996} \\
\hline Regression $\rightarrow$ & \multicolumn{2}{|c|}{$M_{t}{ }^{P}$ on } & \multicolumn{1}{|c|}{$M_{t-1}{ }^{B R}$} & \multicolumn{2}{l|}{$M_{t}{ }^{B R}$ on } & \multicolumn{2}{c|}{$M_{t}{ }^{P}$} \\
\hline Scales $\downarrow$ & Constant & Slope & $R^{2}$ & Constant & Slope & $R^{2}$ \\
\hline Return & $5.31 \mathrm{E}-04$ & $1.36 \mathrm{E}-02$ & 0.001 & $2.75 \mathrm{E}-03$ & $5.54 \mathrm{E}-02$ & 0.001 \\
& $(0.000)$ & $(0.401)$ & & $(0.000)$ & $(0.430)$ & \\
\hline Return.D1 & $2.04 \mathrm{E}-07$ & $-4.42 \mathrm{E}-02$ & 0.010 & $-4.14 \mathrm{E}-07$ & 0.139 & 0.003 \\
& $(0.999)$ & $(0.003)$ & & $(0.999)$ & $(0.088)$ & \\
\hline Return.D1.2 & $7.95 \mathrm{E}-07$ & $-6.37 \mathrm{E}-03$ & 0.001 & $1.12 \mathrm{E}-07$ & $-1.84 \mathrm{E}-02$ & 0.001 \\
& $(0.996)$ & $(0.669)$ & & $(1.000)$ & $(0.812)$ & \\
\hline
\end{tabular}

B: From 1997 to 2000

\begin{tabular}{|c|c|c|c|c|c|c|}
\hline Regression $\rightarrow$ & $M_{t}^{P}$ on & $M_{t-1}^{B R}$ & & $M_{t}^{B R}$ on & $M_{t}^{P}$ & \\
\hline$\overline{\text { Scales } \downarrow}$ & Constant & Slope & $R^{2}$ & Constant & Slope & $R^{2}$ \\
\hline Return & $\begin{array}{l}5.28 \mathrm{E}-04 \\
(0.222) \\
\end{array}$ & $\begin{array}{l}0.272 \\
(0.000) \\
\end{array}$ & 0.062 & $1.91 \mathrm{E}-04$ & 0.270 & 0.085 \\
\hline Return.D1 & $\begin{array}{l}7.95 \mathrm{E}-07 \\
(0.998)\end{array}$ & $\begin{array}{l}9.23 \mathrm{E}-02 \\
(0.002)\end{array}$ & 0.010 & $\begin{array}{l}-4.77 \mathrm{E}-07 \\
(0.999)\end{array}$ & $\begin{array}{l}0.136 \\
(0.000)\end{array}$ & 0.016 \\
\hline Retur & $\begin{array}{l}1.87 \mathrm{E}-06 \\
(0.996)\end{array}$ & $\begin{array}{l}0.181 \\
(0.000)\end{array}$ & 0.032 & $\begin{array}{l}-7.47 \mathrm{E}-07 \\
(0.998)\end{array}$ & $\begin{array}{l}0.224 \\
(0.000)\end{array}$ & 0.054 \\
\hline
\end{tabular}

C: From 2001 To 2003

\begin{tabular}{|c|c|c|c|c|c|c|}
\hline Regression $\rightarrow$ & $M_{t}^{P}$ on & $M_{t-1} B R$ & & $M_{t}^{B R}$ on & $M_{t}^{P}$ & \\
\hline Scales $\downarrow$ & Constant & Slope & $R^{2}$ & Constant & Slope & $R^{2}$ \\
\hline Return & $\begin{array}{l}-7.35 \mathrm{E}-04 \\
(0.072)\end{array}$ & $\begin{array}{l}0.259 \\
(0.000)\end{array}$ & 0.041 & $\begin{array}{l}2.40 \mathrm{E}-04 \\
(0.455)\end{array}$ & $\begin{array}{l}0.212 \\
(0.001)\end{array}$ & 0.070 \\
\hline Return.D1 & $\begin{array}{l}2.16 \mathrm{E}-06 \\
(0.994)\end{array}$ & $\begin{array}{l}-1.95 \mathrm{E}-02 \\
(0.677)\end{array}$ & 0.000 & $\begin{array}{l}-4.42 \mathrm{E}-06 \\
(0.984)\end{array}$ & $\begin{array}{l}0.148 \\
(0.000) \\
\end{array}$ & 0.032 \\
\hline Retr & $\begin{array}{l}1.80 \mathrm{E}-06 \\
(0.996)\end{array}$ & $\begin{array}{l}0.164 \\
(0.001)\end{array}$ & 0.016 & $\begin{array}{l}-2.10 \mathrm{E}-06 \\
(0.994)\end{array}$ & $\begin{array}{l}0.184 \\
(0.000)\end{array}$ & .048 \\
\hline
\end{tabular}


where

- P-values of t-tests are given in parentheses.

- $M^{I R L}, M^{U K}, M^{P}, M^{U S}, M^{B R}, M^{J P}$ and $M^{H K}$ are indicators of Irish, UK, Portuguese, US, Brazilian, Japanese and the Hong Kong market indices respectively.

- Return is an indicator of the row daily returns series.

- Return.D1 is an indicator of the returns series reconstructed by using the first wavelet crystal.

- Return.D1+D2 is an indicator of the returns series reconstructed by using the first and the second wavelet crystals together. 


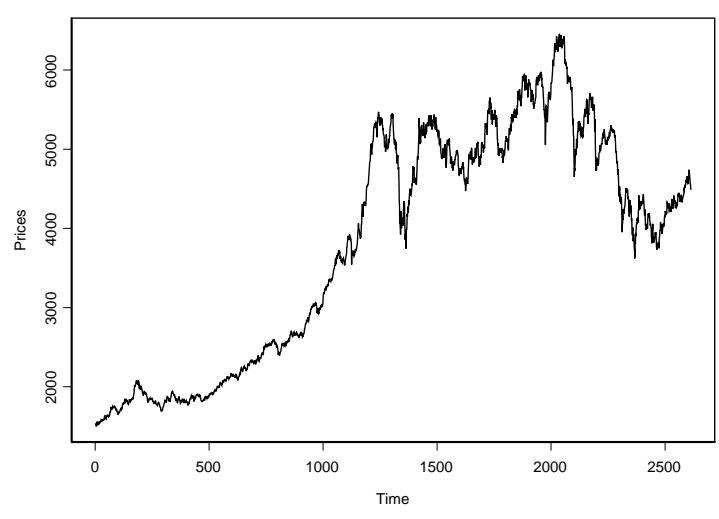

(a) ISEQ Overall index.

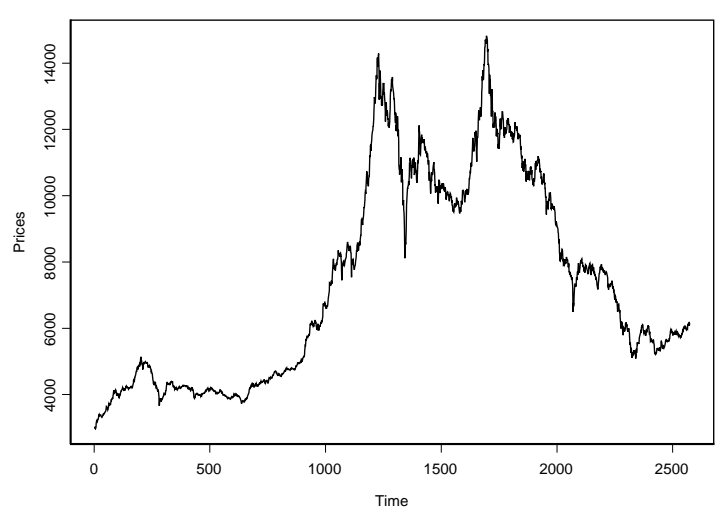

(c) PSI20 index.

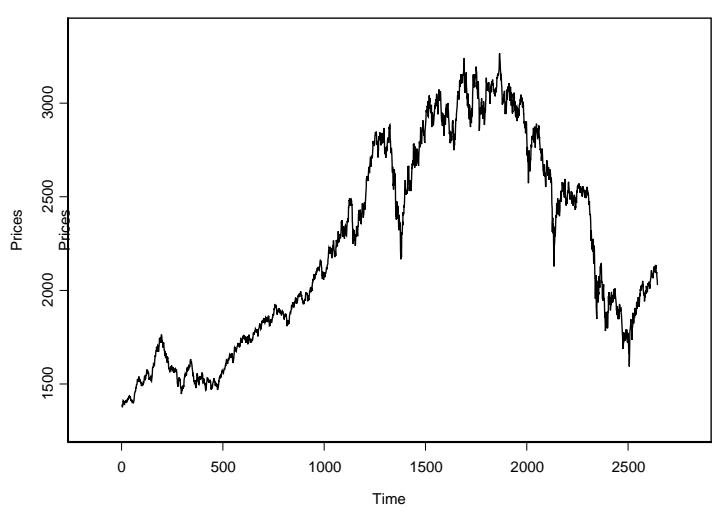

(b) FTSE all share index.

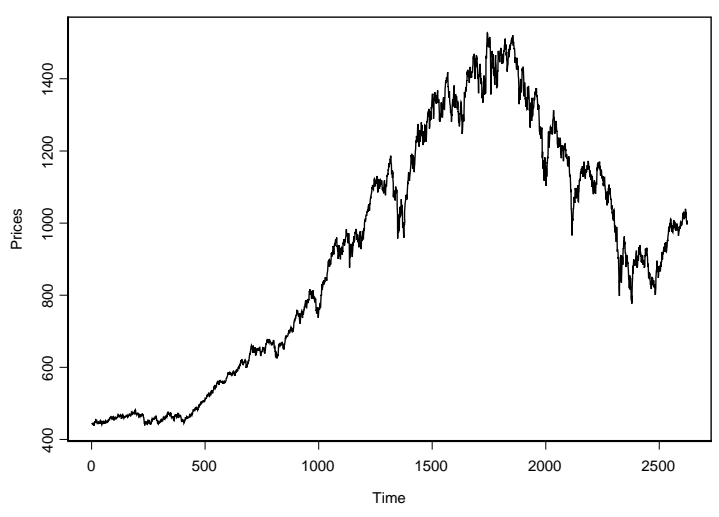

(d) S\&P500 index. 


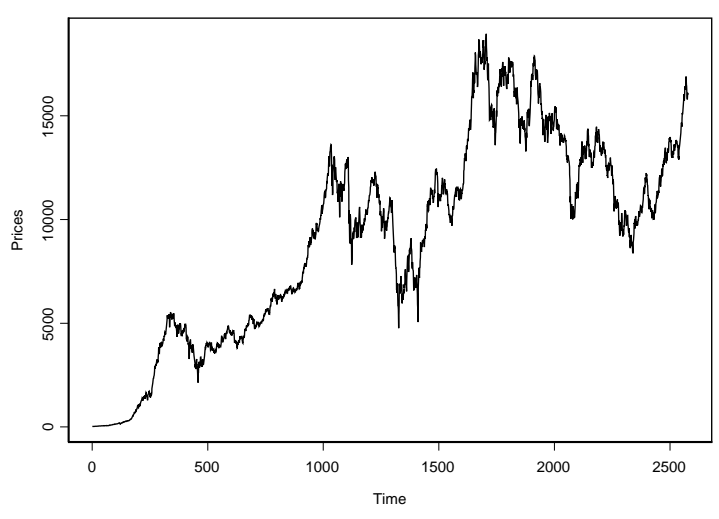

(e) Bovespa index.

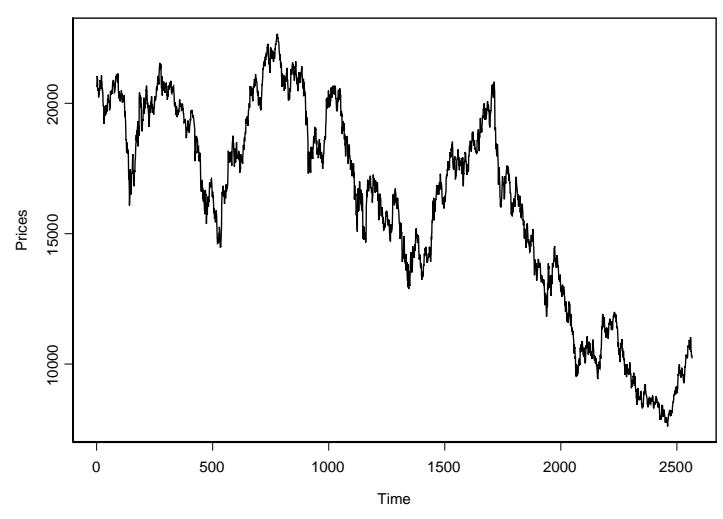

(f) Nikkei 225 index.

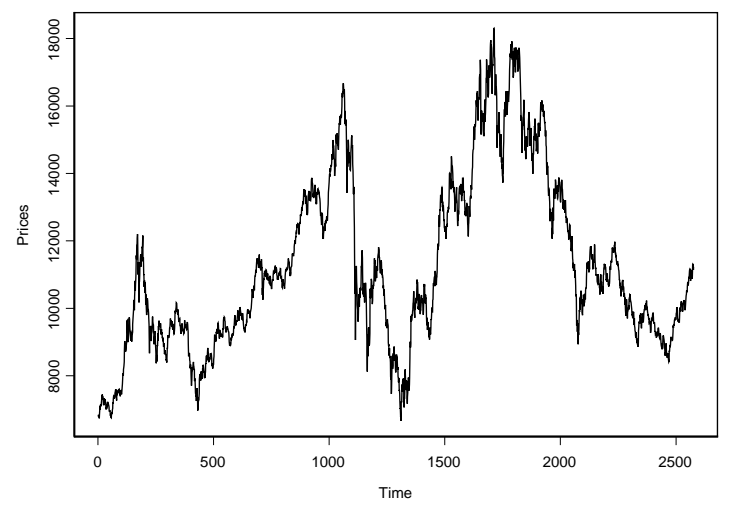

(g) HSI index.

Figure 1: The daily prices from May $1^{\text {st }}, 1993$ to Septemeber $30^{\text {th }}, 2003$. 


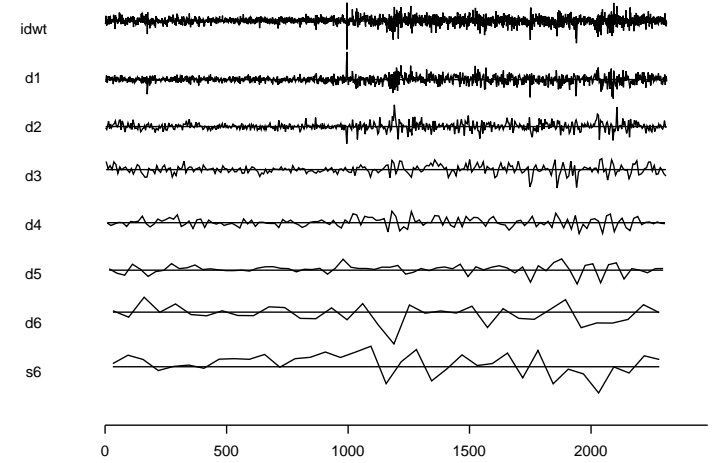

(a) ISEQ Overall index.

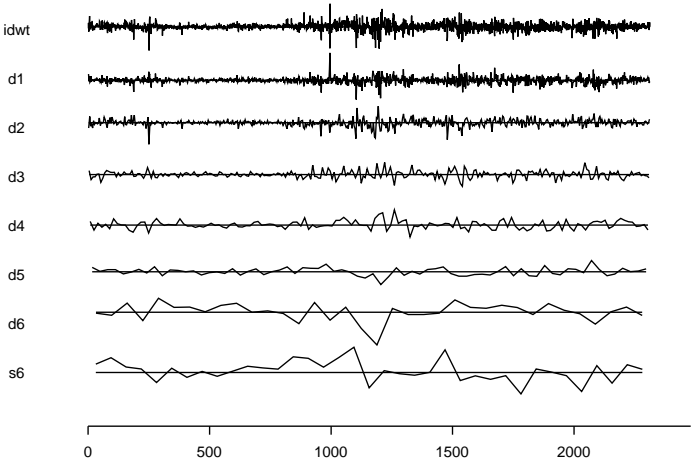

(c) PSI20 index.

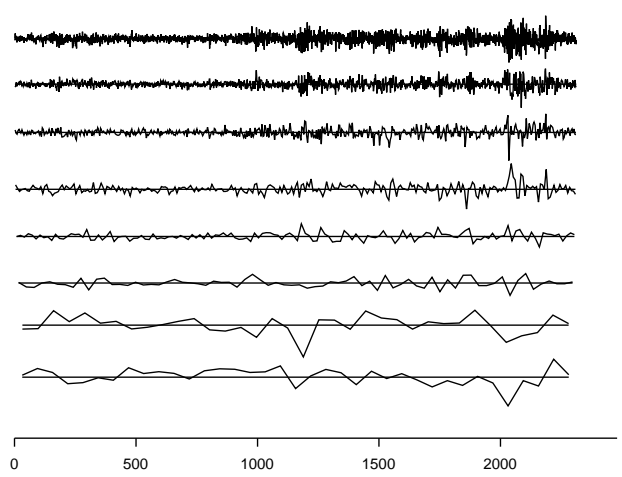

(b) FTSE all share index.

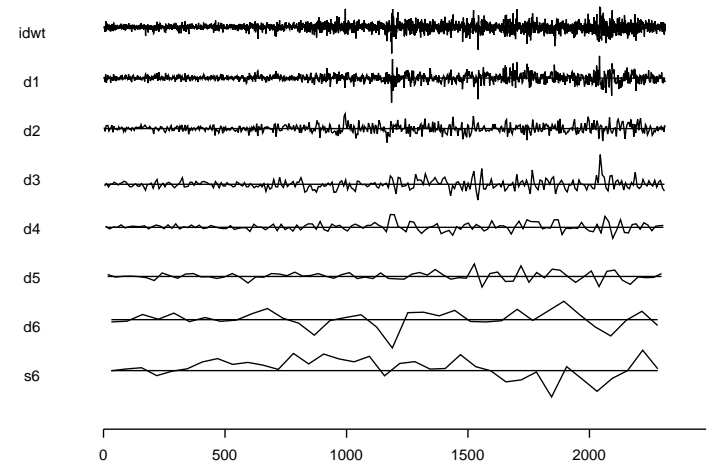

(d) S\&P500 index. 


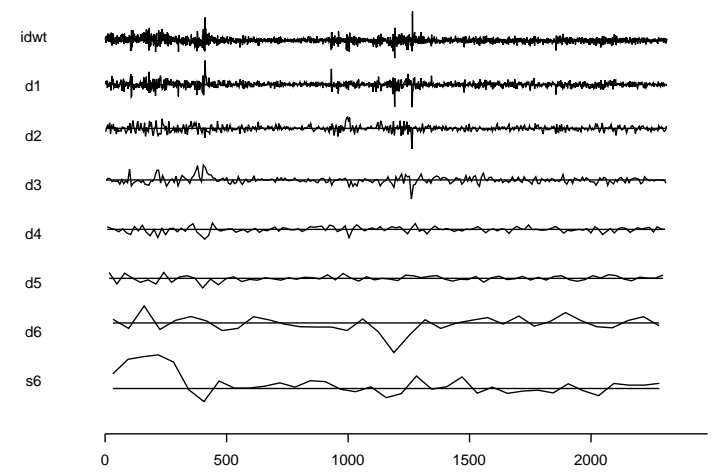

(e) Bovespa index.

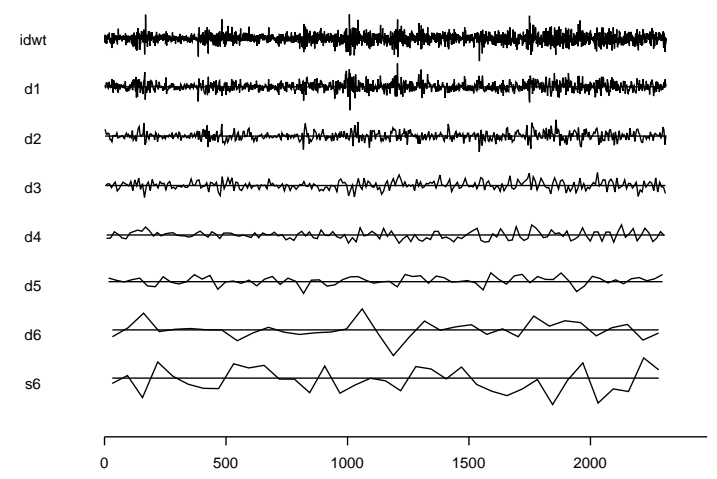

(f) Nikkei 225 index.

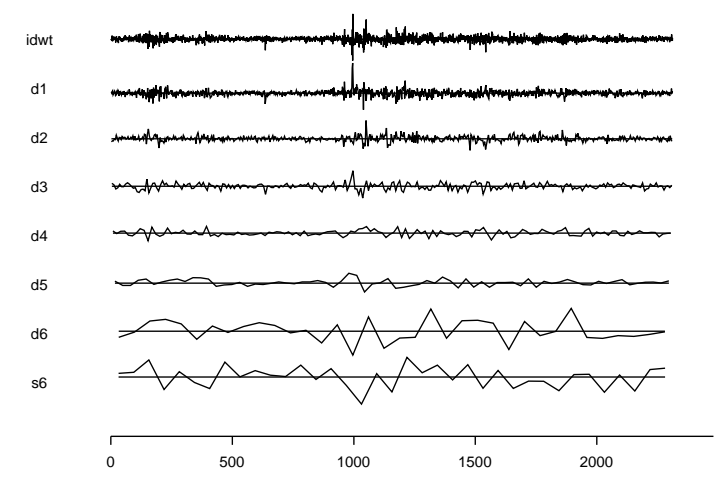

(g) HSI index.

Figure 2: The discrete wavelet transform (DWT) of daily returns vs. Time. 